\title{
Menuju Sistem Pendidikan Global
}

\author{
Ananta Saputra . \\ Alumni Universitas Negeri Semarang
}

Education closely relates to globalization, because it is impossible to ignore globalization process through which a global society will be formed. Parallel with this, Indonesia should reform its education process, focusing on the establishment of an education system which is comprehensive and flexible, in order for its graduates to function effectively in a democratic global social life. Therefore, the education should be designed as such that students can develop their natural potencies and creativities in a freedom, equal and responsible atmosphere. The education should also produces graduates who can conceive their society, together with various factors causing their successes or failures. One of alternatives that should be done is to develop a global-based education.

Keywords: education, globalization, reform, global-based education

$D e n d$ endidikan adalah ajang pertarungan ideologis, sebab pada kenyataannya apa yang menjadi tujuan pendidikan saat ini berbenturan dengan kepentingan yang lain, lembaga pendidikan adalah wilayah di mana kesadaran diperebutkan oleh kepentingan: kepentingan untuk membebaskan manusia peserta didik dengan kesadaran dan dorongan untuk terlibat aktif. dalam aktivitas yang mengarah pada kemanusiaan dengan kepentingan untuk menjadikan peserta didik hanya tünduk pada "kesadaran" yang dapat melanggengkan sistem penindasan dan menjadikan peserta didik hanya sebagai obyek dalam pembangunan budaya yang menguntungkan kekuasaan yang menindas kemanusiaan.

Hakekat manusia adalah sadar akan lingkungannya, ini biasa ditempuh dengan menggunakan kapasitas hati dan pikiran untuk berpengetahuan. Dunia adalah taman firdaus dengan hati dan pikiran sebagai pintu gerbangnya, demikian ungkap Kahlil Gibran. Dalam konteks ini cinta adalah kekuatan aktif yang melibatkan ilmu pengetahuan dan perasaan. Tanpa pengetahuan, orang hanya akan tunduk kepada kebodohan, cinta buta yang tidak menjadi semangat untuk melihat relasi antar manusia secara obyektif, tetapi hanya berlandaskan subyektivitas yang kecenderungannya adalah memaksakan kehendak.

Tapi apa daya, manusia adalah produk dari masyarakat juga, apalagi manusia di negeri ini yang selalu dijauhkan dari pendidikan dan didekatkan pada mitos, tahayul dan sentimen-sentimen yang sempit, lalu kapitalisme pasar bebas juga menjadikan manusia hanya tunduk pada egonya: ego species yang menghinggapi makhluk manusia, ego yang tidak biasa membukakan pikiran dan hati untuk mewujudkan harmoni kehidupan sebagai manusia yang autentik. Ego spisies inilah yang membuat mereka (species manusia) merasa sudah menjadi manusia (dalam pengertian kualitatif), merasa sudah jadi $f i$ akhsani taqwiim (manusia dalam sebaik- 
baik bentuk). Padahal mereka sama sekali belum sedikit pun berpikir tentang para meter apa yang menyebabkan mereka disebut sebagai manusia, mereka mengaku berbeda dengan spisies lain, misainya hewan dan tumbuh-tumbuhan. Tetapi sekali lagi apakah hanya dengan aktivitas berupa makan, minum, seks, dan pelampiasanpelampiasan kebutuhan yang juga dimiliki makhluk lain telah memberikan penjelasan bahwa mereka "manusia jadi"

Ada kemungkinan bahwa makhluk lain punya juga memiliki perasaan kememadaian ternadap realitas spisiesnya. Binatang juga melakukan makan, minum, seks dan aktivitas lain seperti saling memangsa, dan sebagainya. Mereka merasa puas dengan eksistensi dirinya, artinya mereka juga memiliki ego spisies, sebagai analogi dan anekdot: apakah anjing seandainya ia mampu merasa dan berpikir, akan merasa bahwa mereka lebih rendah dari manușia? Tidak, ketika menggonggong pada saat melihat kita karena dirasa kita akan mengganggunya, mereka barangkali juga mengumpat: "dasar manusia spisies rendahan, nggak ngerti bahasa anjing. Kita pun ngomong: tepatnya ego spisies ini adalah mumi watak "manusia yang juga binatang watak spisies rendahan yang perlu dituntaskan adalah dengan menata strukturyang lebih kondusif bagi perkembangan kepribadian.

\section{Pendidikan Sebelum Merdeka}

Bangsa Indonesia telah mengalami berbagai bentuk praktek pendidikan: praktek pendidikan Hindu, pendidikan Budhis, pendidikan Islam, pendidikan zaman VOC, pendidikan kolonial Belanda, pendidikan zaman pendudukan Jepang, dan pendidikan zaman setelah kemerdekaan. Berbagai praktek pendidikan memiliki dasar filosofis dan tujuan yang berbeda-beda. Beberapa praktek pendidikan yang relevan dengan pembahasan ini adalah praktek-praktek pendidikan modem zaman kolonial Belanda, praktek pendidikan zaman kemerdekaan sampai pada tahun 1965, dan praktek pendidikan dalam masa pembangunan sampai sekarang ini.

Praktek pendidikan zaman kolonial Belanda ditujukan untuk mengembangkan kemampuan penduduk pribumi secepatcepatnya melalui pendidikan Barat. Diharapkan praktek pendidikan Barat ini akan dapat mempersiapkan kaum pribumi menjadi kelas menengah baru yang mampu menjabat sebagai "pangreh praja". Praktek pendidikan kolonial ini tetap menunjukkan diskriminasi antara anak pejabat dan anak kebanyakan. Kesempatan luas tetap saja diperoleh anak-anak dari lapisan atas. Dengan demikian, sesungguhnya tujuan pendidikan adalah demi kepentingan penjajah untuk dapat melangsungkan penjajahannya. Yakni, menciptakan tenaga kerja yang dapat menjalankan tugas-tugas penjajah dalam mengeksploitasi sumber dan kekayaan alam Indonesia. Di samping itu, dengan pendidikan model Barat akan diharapkan muncul kaum bumi putera yang berbudaya barat, sehingga tersisih dari kehidupan masyarakat kebanyakan. Pendidikan zaman Belanda membedakan antara pendidikan untuk orang pribumi. Demikian pula bahasa yang digunakan berbeda. Namun perlu dicatat, betapapun juga pendidikan Barat (Belanda) memiliki peran yang penting dalam melahirkan pejuang-pejuang yang akhirnya berhasil melahirkan kemerdekaan Indonesia.

Pada zaman Jepang meski hanya dalam tempo yang singkat, tetapi bagi dunia pendidikan Indonesia memiliki arti yang amat signifikan. Sebab, lewat pendidikan Jepang-lah sistem pendidikan disatukan. Tidak ada lagi pendidikan bagi orang asing degan pengantar bahasa Belanda. 
Satu sistem pendidikan nasional tersebut diteruskan setelah bangsa Indonesia berhasil merebut kemerdekaan dari penjajah Belanda. Pemerintah Indonesia berupaya melaksanakan pendidikan nasional yang berlandaskan pada budaya bangsa sendiri. Tujuan pendidikan nasional adalah untuk menciptakan warga negara yang sosial, demokratis, cakap dan bertanggung jawab dan siap sedia menyumbangkan tenaga dan pikiran untuk negara. Praktek pendidikan selepas penjajahan menekankan pengembangan jiwa patriotisme. Dari pendekatan "Macrocosmics", bisa dianalisis bahwa praktek pendidikan tidak bisa dilepaskan dari lingkungan, baik lingkungan sosial, politik, ekonomi maupun lingkungan lainnya. Pada masa ini, lingkungan politik terasa mendominasi praktek pendidikan. Upaya membangkitkan patriotisme dan nasionalisme terasa berlebihan, sehingga menurunkan kualitas pendidikan itu sendiri. $\mathrm{Hal}$ ini sangat terasa terutama pada periode Orde Lama (tahun 1959 - 1965)

\section{Pendidikan Setelah Merdeka}

Praktek pendidikan zaman Indonesia merdeka sampai tahun 1965 dapat dikatakan banyak dipengaruhi oleh sistem pendidikan Belanda. Sebaliknya, pendidikan setelah tahun 1966 pengaruh sistem pendidikan Amerika semakin lama terasa semakin menonjol. Sistem pendidikan Amerika menekankan bahwa praktek pendidikan merupakan instrumen dalam proses pembangunan. Tidak mengherankan kalau seiring dengan semangat dan pelaksanaan pembangunan yang dititikberatkan pada pembangunan ekonomi, praktek pendidikan dijadikan alat untuk dapat mendukung pembangunan ekonomi dengan mempersiapkan tenaga kerja yang diperlukan dalam pembangunan. Dengan kata lain praktek pendidikan yang bersumber pada kebijaksanaan pendidikan banyak ditentukan guna kepentingan pembangunan ekonomi.

Perkembangan pendidikan nasional yang berkiblat pada pendidikan Amerika berkembang pesat dan menunjukkan hasil yang luar biasa. Namun periu dicatat bahwa kecepatan perkembangan pendidikan nasional ini cenderung mendorong pendidikan ke arah sistem pendidikan yang bersifat sentralistis. Hal ini dapat ditunjukkan dengan semakin berkembangnya birokrasi untuk menopang proses pengajaran tradisional yang semuanya mengarah pada rigiditas. Birokrasi pusat cenderung menekankan proses pendidikan secara klasikal dan bersifat mekanistis. Dengan demikian proses pendidikan cenderung diperlakukan sebagaimana sebuah pabrik. Akibatnya pihak-pihak yang terkait dalam pendidikan, khususnya guru dan murid sebagai individu yang memiliki "kepribadian" tidak banyak mendapatkan perhatian kurikulum, guru dan aturan serta prosedur pelaksanaan pengajaran di sekolah dan juga di kelas ditentukan dari pusat dengan segala wewenangnya. Misalnya, keharusan mengajar dengan menggunakan pendekatan CBSA, kokurikuler dalam bentuk kliping koran.

Lebih lanjut, sentralisasi dan berkembangnya birokrasi pendidikan yang semakin luas dan kaku akan menjadikan keseragaman sebagai suatu tujuan. Hasilnya, berkembanglah manusia-manusia dengan mentalitas "juklak" dan "juknis" yang siap diberlakukan secara seragam. Akibat lebih jauh di masyarakat berkembang prinsip persetujuan sebagai kunci sukses; promosi dan komunikasi adalahi komando; interaksi dicampurkan dengan pertemuan-pertemuan 
resmi; dan stabilitas yang dikaitkan dengan tindakan yang tidak mengandung emosi.

Kemerosotan kuaiitas pendidikan dikarenakan ketidak-mampuan organisasi sekolah menyesuaikan dengan perkembangan dan kebutuhan lingkungan sebagai akibat dari birokratisasi dunia, kualitas pendidikan yang bersifat sentralistis, maka untuk meningkatkan kualitas pendidikan harus didasarkan pada kebijaksanaan debirokratisasi dan desentralisasi.

Desentralisasi pendidikan merupakan suatu tindakan mendelegasikan wewenang kepada satuan kerja yang langsung berhubungan dengan peserta didik. Permasalahannya yang lebih mendalam yang perlu diperfanyakan adalah "apakah kebijaksanaan desentralisasi yang dilaksanakan untuk seluruh fungsi dan kekuasaan sekolah-sekolah ataukah hanya untuk pembagian tugas-tugas administrasi? Apakah kebijaksanaan desentralisasi hanya dilihat sebagai cara untuk mencapai efisiensi dengan mengurangi upaya untuk transformasi baik sistem maupun proses pendidikan?"

Kalau desentralisasi hanya sekadar mengurangi beban tanggung jawab di puncak kekuasaan dengan memberikan sebagian tugas-tugas administrasi kepada aparat yang lebih rendah maka desentralisasi tidak akan banyak artinya sebagai sarana peningkatan kualitas pendidikan. Dewasa ini ketidak-mampuan sekolah meningkatkan kualitas pendidikan mencerminkan ketidak-mampuan struktur dan sistem persekolahan. Kalau tidak ada perubahan yang mendasar pada sistem pendidikan, maka segala upaya peningkatan kualitas akan sia-sia. Oleh karena itu, kebijaksanaan yang diperlukan di dunia pendidikan kita sekarang ini adalah desentralisasi yang mendasar.
Ada beberapa tujuan yang perlu dicapai dengan kebijaksanaan desentralisasi. Pertama, sistem persekolahan harus lebih tanggap terhadap kebutuhan individu peserta didik, guru, dan sekolah. Kedua, iklim pendidikan harus menguntungkan untuk pelaksanaan proses pendidikan.

Di samping mempertanyakan kualitas output pendidikan yang berkiblat ke Amerika ini, mulai dirasakan bahwa praktek pendidikan cenderung mendorong munculnya generasi terdidik yang bersifat materialistik, individualistik dan konsumtif. Hal ini sesungguhnya merupakan konsekuensi logis dari pengetrapan praktek pendidikan Amerika. Apalagi, pusat-pusat pendidikan yang lain, misalnya media komunikasi massa mendukung proses "Amerikanisasi" ini.

Adapula satu bentuk produk proses pendidikan yang sesungguhnya menyimpang dari apa yang terjadi di Barat yakni munculnya mentalitas "jalan pintas", dengan semangat dan kemauan untuk dapat mendapatkan hasil secepat mungkin, baik di kalangan generasi muda maupun generasi tuanya. Mereka cenderung tidak menghiraukan bahwa segala sesuatu harus melewati proses yang memerlukan waktu. Bahkan tidak jarang waktu yang diperlukan melewati rentang waktu kehidupannya, tetapi demi masa depan generasi yang akan datang generasi sekarang harus merelakannya. Sebagai contoh, di Barat tidak jarang pembuatan "minuman anggur", agar memiliki rasa luar biasa memerlukan waktu puluhan bahkan ratusan tahun. Tidak jarang pada label sebotol anggur dituliskan: "dibuka 100 atau 200 tahun lagi". Mentalitas "jalan pintas" merupakan hasil negatif dari penekanan yang berlebihan pendidikan sebagai instrumen pembangunan ekonomi. Aspek negatif lain yang erat kaitannya dengan mentalitas jalan pintas adalah 
dominannya nilai ekstrik (Extrinsic Value) di kalangan masyarakat kita, khususnya generasi muda.

Tekanan kemiskinan menimbulkan obsesi bahwa kekayaan merupakan obat yang harus segera diperoleh dengan segala cara dan dengan biaya apapun juga. Oleh karena tujuan segala kegiatan adalah "kekayaan", dan yang lainnya merupakan instrumental variabel untuk mencapai kekayaan tersebut. Oleh karena itu pendidikan, politik bahkan agama dijadikan sarana dan alat untuk mendapatkan kekayaan. Pendidikan, secara khusus, akan diberlakukan sebagai lembaga yang mencetak "tenaga kerja", bukan lembaga yang menghasilkan "manusia yang utuh" (the whole person). Konsep tersebut akan menimbulkan tekanan yang berlebihan pada hasil tanpa menikmati prosesnya. Sekolah dijalani oleh seseorang agar mendapatkan ijazah untuk bekerja. Proses sekolahnya sendiri tidak pernah dinikmati, karena tidak penting.

Dua mental tersebut bisa menjadi faktor yang akan merusak kehidupan masyarakat. Perlu ada upaya untuk mengembalikan kesadaran di kalangan masyarakat khususnya generasi muda; pentingnya pencapaian tujuan jangka panjang, memahami makna proses yang harus, dilalui dan menyadari akan pentingnya nilai-nilai yang harus muncul dari diri sendiri.

\section{Pengaruh Budaya terhadap \\ Pendidikan}

Berbagai penyimpangan yang ada dalam masyarakat, misalnya membesarkan jumlah pengangguran, berkembangnya mentalitas jalan pintas, sikap materialistik dan individualistik, dominannya nilai-nilai ekstrinsik terutama di kalangan generasi muda, dari satu sisi dapat dikaitkan dengan kegagalan praktek pendidikan yang berkiblat ke Amerika. Dengan kata lain, praktek pendidikan yang dilaksanakan tidak atau kurang cocok dengan budaya indonesia. Untuk itu, perlu dicari sosok bentuk praktek pendidikan yang berwajah Indonesia.

Pendidikan merupakan proses yang berlangsung daiam suatu budaya tertentu. Banyak nilai-nilai budaya dan orientasinya yang bisa menghambat dan bisa mendorong pendidikan. Bahkan banyak pula nilai-nilai budaya yang dapat dimanfaatkan secara sadar dalam proses pendidikan. Sebagai contoh di Jepang "moral Ninomiya Kinjiro" merupakan nilai budaya yang dimanfaatkan praktek pendidikan untuk mengembangkan etos kerja. Kinjiro adalah anak desa yang miskin yang belajar dan bekerja keras sehingga dapat menjadi samurai, suatu jabatan yang sangat terhormat. Saking miskinnya, orang tuanya tidak mampu membeli alat penerangan. Dalam belajar ia menggunakan penerangan dari kunangkunang yang dimasukan dalam botol. Kerja keras diterima bukan sebagai beban, melainkan dinikmati sebagai pengabdian. Selain semangat kerja keras, budaya Jepang juga menekankan rasa keindahan yang tercerminkan pada ketekunan, hemat, jujur dan bersih sebagaimana semangat Kinjiro diwujudkan dalam patung anakyang sedang asyik membaca sambil berjalan dengan menggendong kayu bakar di bahunya. Patung tersebut didirikan di setiap sekolah di Jepang.

Dalam kaitan ini perlu dipertanyakan adakah nilai-nilai dan orientasi budaya kita yang bisa dimanfaatkan dalam praktek pendidikan? Manakah nilai dan orientasi budaya yang perlu dikembangkan dan manakah yang harus ditinggalkan?

Untuk dapat menjawab pertanyaan tersebut di atas perlu dilaksanakan 
serangkaian penelitian yang bersifat multidisipliner.

\section{Evaluasi dan Pentingnya Penelitian}

Tidak berlebihan kalau dikatakan bahwa ilmu pendidikan di Indonesia mandeg dan pendidikan kita yang lebih berwajah keAmerika-an hanya merupakan salah satu akibat kemandegan ilmu pendidikan. Kalau ditelusuri lebih jauh, kemandegan ilmu pendidikan disebabkan terutama karena kualitas penelitian pendidikan yang rendah. Dengan demikian upaya mencari pendidikan yang berwajah ke-indonesia-an harus disertai dengan peningkatan kualitas pendidikan.

Agenda penelitian untuk menemukan pendidikan yang berwajah ke-indonesia-an bisa dimulai dari, pertama, penelitian untuk menemukan nilai-nilai dan orientasi budaya daerah (setempat) yang memiliki nilai positif bagi praktek pendidikan. Misalnya, nilai "Ratu adil di dukung, ratu zalim disanggah", adalah nilai yang mendukung keadilan sosial.

Kedua, penelitian yang membandingkan nilai-nilai yang berkaitan dengan proses pendidikan di rumah (keluarga) dan pendidikan di sekolah. Misalnya, nilai penekanan orang tua untuk memerintah langsung anak atau mendikte anak di satu pihak dan tekanan dalam proses belajar mengajar di sekolah. Sudah barang tentu kedua nilai tersebut bertentangan. Bagaimanakah akibatnya terhadap perkembangan anak didik?

Ketiga, penelitian yang menjawab makna konsep yang tercantum pada falsafah dan dasar negara. Misalnya, dalam alenia pembukaan UUD 1945 tercantum konsep "bangsa yang cerdas". Apa maknanya bangsa yang cerdas? Apakah makna kecerdasan sama antara masyarakat agraris dan masyarakat industri atau bahkan pada masyarakat informatif. Artinya, kecerdasan apakah yang harus dimiliki untuk menuju masyarakat industri atau masyarakat yang dilanda globalisasi?

Keempat, penelitian yang mencari titik temu antara pendidikan sistem persekolahan dan pendidikan luar sekolah. Sebab, pada masyarakat industri hubungan antara kedua sistem pendidikan tersebut memiliki peran yang penting.

Kelima, penelitian yang memusatkan pada kebijaksanaan pendidikan. Misalnya, sejauh mana terdapat keterkaitan antara kebijaksanaan rayonisasi? Siapakah yang menikmati anggaran pemerintah di bidang pendidikan? Bagaimanakah penduduk miskin dapat menikmati pendidikan?

Keenam, penelitian yang mengkaji kecenderungan-kecenderungan yang akan terjadi di masa mendatang. Bagaimanakah dampak atas adanya kecenderungan tersebut bagi dunia pendidikan khususnya dan bagi masyarakat pada umumnya? Bagaimanakah caranya agar kita bisa menguasai dan merubah kecenderungan tersebut?

Ketujuh, penelitian yang mengkaji peran dan interaksi berbagai pusat pendidikan. Misalnya, bagaimana hubungan yang harus dikembangkan antara sekolah dan TPI, sekolah dengan surat kabar dan radio?

Akhirnya, perlu dipikirkan adanya penerbitan dari Kelompok Kajian Pendidikan ke-indonesia-an sebagai media penyebaran pertukaran informasi dengan masyarakat luas.

\section{Ketimpangan dalam Pendidikan}

Kesenjangan sosial merupakan fenomena masyarakat yang bersifat global, terjadi baik di negara maju ataupun 
terbelakang. Bahkan proses integrasi ekonomi global cenderung akan mempertajam perbedaan kelompok kaya dan kelompok miskin. Lembaga studi di Amerika Serikat, misalnya, Institute for Policy Study sebagaimana dimuat pada Herald Tribune, 24 Januari 1997, mengemukakan bahwa ekonomi global akan menciptakan kesenjangan antara kelompok kaya dan kelompok miskin yang luar biasa. Diramalkan bahwa kekayaan dari 447 orang terkaya di dunia akan lebih besar daripada pendapatan penduduk miskin yang mencakup sekitar separo jumlah penduduk dunia, dan dua pertiga penduduk dunia akan mengalami proses pemiskinan. Di bidang tenaga kerja, 200 industri terkemuka dunia akan menguasai sekitar $28 \%$ kegiatan ekonomi dunia, tetapi hanya menyerap $1 \%$ dari tenaga kerja global dengan gaji yang relatif rendah. Bagi negara sedang berkembang, seperti di Indonesia, kesenjangan sosia! bisa merupakan ancaman keamanan nasional sebab ketimpangan sosial ini akan berakumulasi dan bersinergi dengan berbagai persoalan masyarakat yang kompleks. Ujungujungnya, persoalan ketimpangan sosial ekonomi tersebut akan mengganggu proses pembangunan ekonomi. Kesenjangan sosial tidak hanya perlu dijadikan topik pembahasan di berbagai seminar tetapi perlu untuk dicari pemecahannya secara jernih.

Peran apakah yang dapat dilakukan oleh lembaga pendidikan untuk memecahkan persoalan kesenjangan sosial tersebut? Namun, ternyata pendidikan sendiri tidak bebas dari ketimpangan sosial. Banyak paedagog atau sosiolog, seperti Randall Collins dalam The Credentiai Society: An Historical Sosiology of Education and Stratafication, mengemukakan buktibukti bahwa justru pendidikan formal merupakan awal dari proses stratafikasi sosial itu sendiri. Di Indonesia tesis ini didukung dengan adanya pola perjalanan sekolah anak yang berbeda dari kalangan keluarga mampu dan miskin. Anak dari kalangan berada memiliki kesempatan yang lebih luas untuk memasuki sekolah yang baik semenjak dari TK sampai jurusanjurusan pilihan di universitas pilihan. Sebaliknya, sebagian besar anak dari golongan masyarakat yang tidak mampu harus menerima kenyataan bahwa mereka harus rela memasuki sekolah yang tidak berkualitas sepanjang masa sekolahnya.

Tidak jarang sekolah yang jelek yang berada di kota-kota, lebih khusus lagi di kotakota besar cenderung akrab dengan kemiskinan dan keterbelakangan. Di samping itu lingkungan sekolah yang tidak berkualitas cenderung memunculkan kekerasan. Anak-anak dari keluarga miskin yang berada di sekolah-sekolah yang "tidak bermutu" sadar bahwa mereka tidak akan mampu bersaing dengan anak-anak dari sekolah yang "bermutu" yang kebanyakan datang dari keluarga mampu. Mereka, sejak dini sudah dipaksa memendam dendam yang tidak pernah terekspresikan, karena itu, tidak mengherankan anak-anak yang lahir dari kelompok miskin cenderung menjadi penganggur, lingkungan fisik dan psikis tergencet serta dibayangi dengan tindak kejahatan. Hal ini acapkali menjadikan anak memiliki emosi yang tidak stabil, mudah marah, agresif dan frustasi, dan gampang terkena provokasi.

Latar belakang keluarga yang didominasi oleh kemiskinan ini menjadikan mereka yang semula menganggap sekolah sebagai surga, ternata mengalami kenyataan yang berbeda. Di sekolah mereka sering menemui kenyataan betapa sulit untuk menjadikan guru sebagai panutan dan sekaligus pengayom. Interaksi di sekolah 
justru semakin menjadikan mereka frustrasi. Sekolah tidak memberikan kesempatan mereka untuk mengekspresikan diri mereka sendiri. Keadaan bertambah buruk manakala banyak guru dapat dikatakan tidak mampu lagi menciptakan hubungan yang bermakna dengan para siswa dengan baik. Hal ini dikarenakan beban kurikulum yang terlalu sarat di samping kondisi sosial ekonomi menyebabkan guru tidak dapat berkonsentrasi dan melakukan refleksi dalam melaksanakan pengabdian profesionalnya. Tanpa ada kontak yang bermakna dan berkesinambungan antara guru dan siswa, guru tidak akan mampu mengembangkan wawasan siswa mengenai perilaku masa kini demi keberhasilan di masa depan.

\section{Tolok Ukur Ketimpangan}

Dimensi ketimpangan sosial di sekolah sesungguhnya tidak serumit yang terjadi di masyarakat luas. Mark Griffin dan Margaret Batten, peneliti pendidikan berkebangsaan Australia, dalam bukunya 'Equity in Schools: An independent Perspective', mengemukakan dua aspek penting dalam mengkaji ketimpangan di dunia pendidikan. Pertama ujud ketimpangan, yang dapat terjadi dalam ujud input, yakni kesempatan untuk memperoleh pendidikan yang berkualitas, atau ketimpangan dalam ujud output atau hasil pendidikan. Kedua, ukuran ketimpangan, yang dapat diukur pada level individu atau ketimpangan pada level kelompok, seperti kelompok siswa kaya dan miskin, kelompok siswa berasal dari desa dan dari kota, kelompok siswa lakilaki dan siswa pe rempuan. Apa yang dikemukakan oleh kedua peneliti pendidikan tersebut amat penting untuk merencanakan intervensi lewat kebijakan pendidikan guna mengatasi problem ketimpangan pendidikan.
Aspek ketimpangan dalam ujud output pendidikan dipusatkan pada kualitas lulusan baik dalam arti nilai akhir ujian seperti NEM ataupun dalam arti kualitas kemampuan lulusan. Dimensi tersebut dapat dianalisis pada level mikro individual atau dalam level makro atau kelompok. Intern suatu sekolah dapat diketemukan perbedaan prestasi antar siswa yang erat berkaitan dengan latar belakang status sosial masing-masing individu. Tetapi di samping itu, perbedaan diketemukan dalam perbandingn antar kelompok, baik intern satu sekolah maupun antar sekolah. Sekali lagi perbedaan tersebut erat berkaitan dengan status sosial ekonomi kelompok yang bersangkutan.

James Coleman dalam 'Equality of educational opportunity' merupakan sosiolog yang telah membuktikan adanya realitas ketimpangan output pendidikan dalam kaitan dengan ketimpangan inputpada level kelompok di Amerika Serikat. Namun, hanya sekitar $10 \%$ varian ketimpangan outputyang dapat dijelaskan oleh ketimpangan input. Artinya, ketersediaan fasilitas pendidikan, rasio guru-siswa, kualitas guru, hanya memberikan kontribusi kecil dalam menimbulkan ketimpangan output.

Frederick Jenck dalam laporan penelitian Inequity in Education membuktikan ketimpangan output pendidikan dengan menggunakan pada level individual. Namun, kajian ketimpangan pendidikan yang didasarkan pada output pendidikan dikritik keras oleh John Keevess, lewat artikelnya Equitable Opportunities in Australian education, sebab pendekatan output menjadikan ketimpangan pendidikan sebagai sesuatu yang tidak mungkin dipecahkan dan upaya mengatasi ketimpangan lebih tepat disebut sebagai suatu ilusi.

Sebaliknya, pendekatan input lebih praktis dan lebih operasional. Pendekatan 
ini melihat adanya ketimpangan pendidikan dalam ujud bahwa siswa mendapatkan kesempatan untuk menikmati fasilitas pendidikan yang tidak sama. Perbedaan ini bisa berupa kualitas guru, prasarana dan fasilitas pendidikan, dan sebagainya. Ketimpangan pendidikan dalam kesempatan untuk mendapatkan fasilitas pendidikan dapat dianalisis pada level individu ataupun kelompok. Ketimpangan input dan proses ini lebih mudah diatasi dengan menyediakan fasilitas yang diperlukan. Perbedaan antar individu dalam suatu sekolah dapat diatasi, misalnya, dengan penyediaan fasilitas buku sehingga setiap siswa bisa menggunakan satu buku. Tetapi, pengalaman di banyak negara sedang berkembang termasuk di Indonesia menunjukkan bahwa kualitas input tidak selamanya akan meningkatkan output pendidikan, sebagaimana disimpulkan oleh Coleman di atas. Sebab, dibalik kesamaan fisik yang diperoleh oleh masing-masing individu muncul pertanyaan apakah siswa dengan latar belakang sosial ekonomi tinggi mendapatkan pelayanan yang sama dengan siswa yang berasal dari keluarga miskin? Apakah guru benar-benar dapat berperilaku adil terhadap semua siswa tanpa melihat latar belakang mereka?

Dengan mendasarkan pada dua dimensi di atas, ketimpangan sekolah dapat dikelompokkan dalam empat varian: a) ketimpangan dalam ujud input dalam ukuran individual, b) ketimpangan dalam ujud input dalam ukuran kelompok, c) ketimpangan dalam ujud output dalam ukuran individual, dan, d) ketimpangan dalam ujud output dalam ukuran kelompok. Pemecahan permasalahan ketimpangan masing-masing kelompok memerlukan kebijakan intervensi yang berbeda.

Proses sekolah dewasa ini senantiasa menekankan pengembangan siswa sebagai individu, sekolah tidak pernah mengembang- kan siswa secara bersama sebagai suatu kelompok. Mulai dari tugas-tugas harian, tanya jawab dan diskusi di kelas sampai evaluasi akhir hasil studi, semua itu merupakan tugas invidual. Dalam persaingan untuk mencapai prestasi di antara siswa ini sekolah sama sekali tidak menanamkan semangat kerjasama dan solidaritas sosial. Layaknya pada persaingan bebas di dunia ekonomi siapa yang kuat akan berkembang, demikian pula di dunia pendidikan. Panekanan pada pengembangan siswa secara individual menyebabkan kesenjangan hasil pendidikan. Ditambah lagi, setiap pembaharuan pendidikan pada umumnya senantiasa menguntungkan siswa yang relatif mampu dan berdomisili di kota-kota, sehingga kesenjangan pendidikan semakin tajam. Sebagai contoh, pengenalan matematika modern menyebabkan kesenjangan prestasi siswa baik pada level individual maupun level kelompok semakin menganga.

\section{Sejalan dengan perlunya} dikembangkan solidaritas sosial di kalangan siswa, pendekatan individu dalam dunia pendidikan perlu diimbangi dengan pendekatan yang berbasis kerjasama, kebersamaan dan kolaborasi untuk mengembangkan kemampuan siswa dalam kerjasama, dan kemampuan bernegosiasi, berkomunikasi serta kemampuan untuk mengambil keputusan. Salah satu pendekatan dalam proses belajar mengajar yang berbasis kelompok adalah Cooperative Leaming. Kebersamaan dan kerjasama dalam pembelajaran merupakan kerjasama di antara para siswa untuk mencapai tujuan belajar bersama. Di samping tujuan bersama yang akan dicapai, kebersamaan dan kerjasama dalam pembelajaran ìni juga diarahkan untuk mengembangkan kemampuan kerjasama di 
antara para siswa. Dengan pendekatan ini, guru tidak selalu memberikan tugas-tugas secara individual, melainkan secara kelompok. Bahkan penentuan hasil evaluasi akhirpun menggunakan prinsip kelompok. Artinya, hasil individu siswa tidak hanya didasarkan kemampuan masing-masing, tetapi juga dilihat berdasarkan hasil prestasi kelompok. Dengan demikian, siswa yang pandai akan menjadi tutor membantu siswa yang kurang pandai demi prestasi kelompok sebagai satu kesatuan. Setiap siswa tidak hanya bertanggung jawab atas kemajuan dan keberhasilan dirinya, tetapi juga bertanggung jawab atas keberhasilan dan kemajuan kelompoknya.

Berbagai hasil penelitian menyimpulkan mianfaat Cooperative teaming. Robert E. Slavin dan Nancy A. Madden, dalam hasil penelitian tentang "School Practices That improve Race Relations"yang dimuat pada American Educational Research Joumal menyatakan: dibandingkan dengan model pembelajaran yang lain. Cooperative leaming dalam pembelajaran menghasilkan prestasi akademik yang lebih tinggi untuk seluruh siswa, kemampuan lebih baik untuk melakukan hubungan sosial, meningkatkan rasa percaya diri, serta mampu mengembangkan saling kepercayaan sesamanya, baik secara individual maupun kelompok. Secara lebih terperinci hasil penelitian tersebut mengemukakan bahwa bukannya pelatihan guru, buku-buku civics, sejarah, dan diskusi-diskusi di kelas yang mempengaruhi sikap dan perilaku sosial siswa, melainkan tugas-tugas yang diberikan secara kelompok yang secara meyakinkan telah berhasil mengembangkan hubungan, sikap dan perilaku sosial siswa.

Apabila guru melaksanakan proses belajar mengajar dengan mempergunakan Cooperative Leaming, berarti guru tersebut sudah berperan dalam mengurangi. kesenjangan pendidikan khususnya dalam ujud output pada level individual. Di samping itu, berkembangnya kesetiakawanan dan solidaritas sosial di kalangan siswa pada gilirannya akan dapat mengurangi ketimpangan dalam ujud input pada level individual. Demikian pula dapat diharapkan kelak akan muncul generasi baru yang di samping memiliki prestasi akademik yang cemerlang, juga memiliki kesetiakawanan dan solidaritas sosial yang kuat.

Intervensi untuk mengurangi ketimpangan sosial harus dimulai dari lembaga pendidikan.Cooperative Leamingmerupakan suatu kebijakan dalam proses belajar mengajar yang memiliki prospek yang cerah untuk menciptakan equity di dunia pendidikan. Dengan Cooperative Leamingini pula pada hakekatnya merupakan upaya untuk menempatkan proses pendidikan pada rel yang sebenarnya, yakni menghasilkan manusia yang ber-"otak" dan ber"hati".

\section{Pendidikan Berwawasan Global}

Krisis demi krisis mulai dari moneter, ekonomi, politik dan kepercayaan yang tengah melanda bangsa Indonesia, merupakan bukti bahwa sebagai bangsa kita sudah terseret dalam arus globalisasi. Informasi bergerak sedemikian cepat sehingga menimbulkan dampak yang berantai. Demonstrasi menduduki bandara cepat menjadi mode, misalnya.

Pendidikan memiliki keterkaitan erat dengan globalisasi. Pendidikan tidak mungkin menisbikan proses globalisasi yang akan mewujudkan masyarakat global ini. Dalam menuju era globalisasi, Indonesia harus melakukan reformasi dalam proses pendidikan, dengan tekanan menciptakan sistem pendidikan yang lebih komprehensif dan fleksibel, sehingga para lulusan dapat 
berfungsi secara efektif dalam kehidupan masyarakat global demokratis. Untuk itu, pendidikan harus dirancang sedemikian rupa yang memungkinkan para peserta didik mengembangkan potensi yang dimiliki secara alami dan kreatif dalam suasana penuh kebebasan, kebersamaan dan tanggung jawab. Di samping itu, pendidikan harus menghasilkan lulusan yang dapat memahami masyarakatnya dengan segala faktor yang dapat mendukung mencapai sukses ataupun penghalang yang menyebabkan kegagalan dalam kehidupan bermasyarakat. Salah satu altematif yang dapat dilakukan adalah mengembangkan pendidikan yang berwawasan global.

Premis untuk memulai pendidikan berwawasan gobal adalah bahwa informasi dan pengetahuan tentang bagian dunia yang lain harus mengembangkan kesadaran kita bahwa kita akan dapat memahami lebih baik keadaan diri kita sendiri apabila kita memahami hubungan dengan masyarakat lain dan isu-isu global sebagaimana dikemukakan oleh Psikolog Csikszentmihalyi dalam bukunya The Evolving Self: A Psychology for the Third Millenium (1993), yang menyatakan bahwa perkembangan pribadi yang seimbang dan sehat memerlukan "an understanding of the complexities of an increasingly complex and interdependent world".

\section{Perspektif Kurikuler}

Pendidikan berwawasan global dapat dikaji berdasarkan dua perspektif: Kurikuler dan perspektif Reformasi. Berdasarkan perspektif kurikuler, pendidikan berwawasan global merupakan suatu proses pendidikan yang bertujuan untuk mempersiapkan tenaga terdidik kelas menengah dan profesional dengan meningkatkan kemampuan individu dalam memahami masyarakatnya dalam kaitan dengan kehidupan masyarakat dunia, dengan ciriciri: a) mempelajari budaya, sosial, politik dan ekonomi bangsa lain dengan titik berat memahami adanya saling ketergantungan, b) mempelajari berbagai cabang ilmu pengetahuan untuk dipergunakan sesuai dengan kebutuhan lingkungan setempat, dan, c) mengembangkan berbagai kemungkinan berbagai kemampuan dan keterampilan untuk bekerjasama guna mewujudkan kehidupan masyarakat dunia yang lebih baik.

Pendidikan berwawasan global akan menekankan pembahasan materi yang mencakup: a) adanya saling ketergantungan di antara masyarakat dunia, b) adanya perubahan yang akan terus berlangsung dari waktu ke waktu, c) adanya perbedaan kultur di antara masyarakat atau kelompokkelompok dalam masyarakat oleh karena itu perlu adanya upaya untuk saling memahami budaya yang lain, d) adanya kenyataan bahwa kehidupan dunia ini memiliki berbagai keterbatasan antara lain dalam ujud ketersediaan barang-barang kebutuhan yang jarang, dan, e) untuk dapat memenuhi kebutuhan yang jarang tersebut tidak mustahil menimbulkan konflik-konflik.

Berdasarkan perspektif kurikuler ini,pengembangan pendidikan berwawasan global memiliki implikasi ke arah perombakan kurikulum pendidikan. Mata pelajaran dan mata kuliah yang dikembangkan tidak lagi bersifat monolitik melainkan lebih banyak yang bersifat integratif. Dalam arti mata kuliah lebih ditekankan pada kajian yang bersifat multidispliner, interdisipliner dan transdisipliner.

\section{Sudut Pandang ke Arah Reformasi}

Berdasarkan perspektif reformasi, pendidikan berwawasan global merupakan suatu proses pendidikan yang dirancang 
untuk mempersiapkan peserta didik dengan kemampuan dasar intelektual dan tanggung jawab guna memasuki kehidupan yang bersifat sangat kompetitif dan dengan derajat saling ketergantungan antar bangsa yang amat tinggi. Pendidikan harus mengkaitkan proses pendidikan yang berlangsung di sekolah dengan nilai-nilai yang selalu berubah di masyarakat global,oleh karena itu sekolah harus memiliki orientasi nilai, di mana masyarakat kita harus selalu dikaji dalam kaitannya dengan masyarakat dunia.

Implikasi dari pendidikan berwawasan global menurut perspektif reformasi tidak hanya bersifat perombakan kurikulum, melainkan juga merombak sistem, struktur dan proses pendidikan. Pendidikan dengan kebijakan dasar sebagai kebijakan sosial tidak lagi cocok bagi pendidikan berwawasan global. Pendidikan berwawasan global harus merupakan kombinasi antara kebijakan sosial disatu sisi dan disisi lain sebagai kebijakan yang mendasarkan pada mekanisme pasar. Oleh karena itu, sistem dan struktur pendidikan harus bersifat terbuka, sebagaimana layaknya kegiatan yang memiliki fungsi ekonomis.

Kebijakan pendidikan yang berada di antara kebijakan sosial dan mekanisme pasar, memiliki arti bahwa pendidikan tidak semata ditata dan diatur dengan menggunakan perangkat aturan sebagaimana yang berlaku sekarang ini, serba seragam, rinci dan instruktif. Melainkan, pendidikan juga diatur layaknya suatu Mall, adanya kebebasan pemilik toko untuk menentukan barang apa yang akan dijual, bagaimana akan dijual dan dengan harga berapa barang akan dijual. Pemerintah tidak perlu mengatur segala sesuatunya dengan rinci.

Di samping itu, pendidikan berwawasan global bersifat sistemik organik, dengan ciriciri fleksibel-adaptif dan kreatif-demokratis.
Bersifat sistemik-organik berarti sekolah merupakan sekumpulan proses yang bersifat interaktif yang tidak dapat ditihat sebagai hitam-putih, meiainkan setiap interaksi harus dilihat sebagai satu bagian dari keseiuruhan interaksi yang ada.

Fleksibel-Adaptif, berarti pendidikan lebih ditekankan sebagai suatu proses leaming dari pada teaching. Peserta didik dirangsang memiliki motivasi untuk mempelajari sesuatu yang harus dipelajari dan continues leaming. Tetapi, peserta didik tidak akan dipaksa untuk mempelajari sesuatu yang tidak ingin dipelajari. Materi yang. dipelajari bersifat integrated, materi satu dengan yang lain dikaitkan secara padu dan dalam open-system environment. Pada pendidikan ini karakteristik individu mendapat tempat yang layak.

Kreatif-demokratis, berarti pendidikan senantiasa menekankan pada suatu sikap mental untuk senantiasa menghadirkan sesuatu yang baru dan orisinil. Secara paedogogis, kreativitas dan demokrasi merupakan dua sisi dari mata uang. Tanpa demokrasi tidak akan ada proses kreatif, sebaliknya tanpa proses kreatif demokrasi tidak akan memiliki makna.

Untuk memasuki era globalisasi pendidikan harus bergeser ke arah pendidikan yang benwawasan global. Dari perspektif kurikuler pendidikan berwawasan global berarti menyajikan kurikulum yang bersifat interdisipliner, multidisipliner dan transdisipliner. Berdasarkan perspektif reformasi, pendidikan berwawasan global menuntut kebijakan pendidikan tidak semata sebagai kebijakan sosial, melainkan suatu kebijakan yang berada di antara kebijakan sosial dan kebijakan yang mendasarkan mekanisme pasar. Oleh karena itu, pendidikan harus memiliki kebebasan dan bersifat demokratis, fleksibel dan adaptif. 


\section{Tantangan Pengembangan} Sekolah di Masa Depan

Pengalaman pembangunan di negaranegara yang sudah maju, khususnya negara-negara di dunia barat, membuktikan betapa besar peran pendidikan dalam proses pembangunan. Secara umum telah diakui bahwa pendidikian merupakan penggerak utama (prima mover) bagi pembangunan. Secara fisik pendidikan di dunia barat telah berhasil memenuhi kebutuhan tenaga kerja dari segala strata dan segala bidang yang sangat dibutuhkan bagi pembangunan. Dari aspek non-fisik, pendidikan telah berhasil menanamkan semangat dan jiwa modern, yang diujudkan dalam bentuk kepercayaan yang tinggi pada "akal" dan teknologi, memandang masa depan dengan penuh semangat dan percaya diri, dan kepercayaan bahwa diri mereka mempunyai kemampuan (self efficacy) untuk menciptakan masa depan sebagaimana yang mereka dambakan.

Negara-negara sedang berkembang memandang pembangunan yang telah terjadi di dunia barat seakan-akan merupakan cermin bagi diri mereka. Para pemimpin dan ilmiawan di negara sedang berkembang menaruh perhatian yang besar akan peran pendidikan dalam usaha mereka untukmencapai kehidupan yang lebih baik. Pendidikan modern yang telah berhasil mengantarkan negara-negara maju (developped countries) dari kemiskinan dan keterbelakangan pada masa lampau sehingga mencapai tingkat seperti yang bisa disaksikan dewasa ini, sudah barang tentu akan berhasil pula mengantarkan negaranegara yang sedang berkembang mencapai tingkat pembangunan sebagaimana yang telah dicapai negara-negara maju. Maka pendidikan modern barat pun diimpor ke negara yang sedang berkembang. Biaya dan tenaga diarahkan unuk mengembangkan pendidikan. Anggaran belanja di sektor pendidikan terus meningkat. Usaha mendatangkan tenaga ahli dari barat dan mengirim tenaga domestik ke Barat mendapatkan prioritas yang tinggi. Hasil angka buta huruf menurun dengan drastis, gross atau net enrollment rationaik, education achievement dari penduduk semakin tinggi.

Namun, di balik keberhasilan menaikkan pendidikan di kalangan masyarakat, pada tahun 1970-80-an, para ahli mulai melihat tanda-tanda "lampukuning" pada sistem pendidikan pada negara-negara yang sedang berkembang, termasuk di Indonesia, menimbulkan problema: meninggalkan generasi muda dengan pendidikan tetapi tanpa pekerjaan dan memberikan tekanan yang berat pada anggaran belanja. Hal ini disebabkan oleh karena perkembangan di luar pendidikan, khususnya di dunia ekonomi dan teknologi, berlangsung dengan cepat sehingga perkembangan sektor pendidikan tertinggal di belakang. Akibatnya pendidikan tidak lagi berfungsi sebagai pendorong proses kemajuan, melainkan menjadi "pengikut proses kemajuan". Mulailah para ahli, khususnya di bidang pendidikan mempertanyakan teori-teori dan sistem pendidikan yang mereka impor dari barat: relevankah teori dan sistem pendidikan barat diterapkan di dunia sedang berkembang?

Persoalan-persoalan pendidikan dan pembangunan yang terjadi di negara sedang berkembang, termasuk di Indonesia, secara mendasar berbeda dengan problema yang ada di negara-negara Barat. Persoalan pendidikan di Indonesia sangat erat kaitannya dengan falsafah dan budaya bangsa. Winarno Surachmad (1986) memperingatkan "... bahwa ilmu 
kependidikan yang tidak lahir dan tidak tumbuh dari bumi yang diabdinya tidak akan pernah mampu melahirkan potensi untuk menangani masalah yang tumbuh di bumi ini". Pendapat tersebut sangat ekstrim, namun tuntutan bahwa ilmu kependidikan yang akan digunakan untuk memecahkan problema di suatu negara hendaknya tidak lepas dari kondisi budaya setempat memang perlu untuk mendapatkan perhatian dari semua pihak, khususnya dari para perencana dan pengambil keputusan di bidang kebijaksanaan pendidikan. Teori-teori Barat tentang pendidikan dan pembangunan tidaklah senantiasa bersifat universal. Jiwa dan watak bangsa harus menjiwai sistem pendidikan itu sendiri (Winarno, 1986: 5)

\section{Penutup}

Aktivitas pendidikan manapun, peserta didik merupakan obyek sekaligus subyek pendidikan, oleh sebab itu dalam memahami hakikat peserta didik, para pendidik perlu dilengkapi pemahaman tentang ciri-ciri umum peserta didik. Setidaknya secara umum peserta didik memiliki beberapa ciri, antara lain: Pertama, peserta didik dalam keadaan sedang berdaya, maksudnya ia dalam keadaan berdaya untuk menggunakan kemampuan, kemauan, dan sebagainya. Kedua, peserta didik mempunyai keinginan untuk berkembang kearah dewasa. Ketiga, peserta didik mempunyai latar belakang yang berbeda. Keempat, peserta didik melakukan penjelajahan terhadap alam sekitarnya dengan potensi-potensi dasar yang dimiliki secara individu.

Gagasan pendidikan multi cultural berawal dari berkembangnya gagasan dan kesadaran tentang "interkulturalisme" seusai perang dunia II. Kemunculan gagasan dan kesadaran "interkulturalisme" ini selain terkait dengan perkembangan politik internasiona! menyangkut HAM, kemerdekaan dari kolonialisme, dan diskriminasi rasial, juga karena meningkatnya pluralitas di Negara-negara Barat sendiri sebagai akibat dari peningkatan migrasi dari Negara-negara baru merdeka ke Amerika dan Eropa.

Tentu saja, era ini sangat relevan untuk menerapkan pendidikan multikultural karena kontradiksi masyarakat memasuki globalisasi justru semakin jelas. Bahkan konflik interkultural juga semakin marak mewarnai percaturan politik global, nasional dan lokal. Jelas masyarakat kita membutuhkan cara baru dalam memandang realitas, karena sejarah juga berubah.

\section{Daftar Pustaka}

Freire, Paulo. Dkk. 1999. Menggugat Pendidikan. Yogyakarta: Pustaka Pelajar.

lqqbal, Muhammad. 1966. Pembangunan Kembali Alam Pikiran Islam, Osman Raliby (Penerjemah). Jakarta: Bulan Bintang, 1966

Klinken, Gerry van. 2005. Pelaku Baru Identitas Baru : Kekerasan antar Suku pada masa Pacsa Soeharto di Indonesia. dalam Anwar, Dewi Fortuna., Bouvier, Helene., Smith, Glenn., dan Tol, Roger. (Eds). Konflik Kekerasan Intemal Tinjauan Sejarah, Ekonomi-Politik, dan Kebijakan di Asia Pasifik. Jakarta : Yayasan Obor Indonesia.

Mark Olssen, John Codd and Anne-Marie O'Neill. 2004. Education Policy: Globalization, Citizenship and Democracy, London: Sage Publications. 


\section{Menuju Sistem Pendidikan Global; Ananta Saputra}

Ohmae, Kanichi. 1996. Berakhimya Negara Bangsa (Terj.) Sunarto Ndaru Mursito. Dalam Jurnal Analisis CSIS tahun XXV. No. 2.

Paul, Hirst dan Grahame Thompson. 2001. Globalisasi adalah Mitos. Jakarta: Yayasan Obor Indonesia.

Rivinus, T.M. and Larimer, M.E. 2003. Violence, Alcohol, Other Drugs, and the College Studens. Journal of College Student Psychotherapy, 8, 71 - 119.

Roark, M.L. 2003. Conseptualizing Campus Violence : Definitions, Underlying Factors, and Effects. in Leigton, C., Whitaker and Jeffey, Pollard W. (eds,) Campus Violence : Kinds, Causes, and Cures. 1-28. New York: The Haword Press.
Saunders, Peter. 1995. Capitalism. A. Social Audit. Buckingham: Open University Press.

Setiawan, Lingga. Konvensi Hak Anak dan Bangsa yang Beradab, dalam Kompas. Jum'at 24 Februari 2006.

Soemardjan, Selo. 1984. Kesenian Dalam Perubahan Kebudayaan. Dalam Andy Zoelfom (ed). Budaya Sastra. Jakarta: CV. Rajawali.

www.pakguruonline.com

William F. O'Neill, 2001.Ideologi-ideologi Pendidikan, Yogyakarta: Pustaka Pelajar, 2001. 